\title{
John Maynard Keynes of Bloomsbury: Four Short Talks
}

\author{
by \\ Craufurd Goodwin \\ E. Roy Weintraub \\ Kevin D. Hoover \\ Bruce Caldwell
}

17 February 2009

The inaugural event of the Center for the History of Political Economy. Presented at the Nasher Museum of Art, Duke University in conjunction with Vision and Design: A Year of Bloomsbury, a campus-wide interdisciplinary program surrounding an exhibition of Bloomsbury art at the Nasher Museum. 


\section{Abstract \\ of \\ John Maynard Keynes of Bloomsbury: Four Short Talks}

Four talks on Keynes in relation to the Bloomsbury Group: I. Maynard Keynes of Bloomsbury (Craufurd Goodwin); II. Keynes as Policy Advisor (E. Roy Weintraub); III. Keynes and Economics (Kevin D. Hoover); IV. Keynes and Hayek (Bruce Caldwell). The talks were delivered as part of roundtable discussion on John Maynard Keynes of Bloomsbury, the inaugural event of the Center for the History of Political Economy at Duke University, and were held in conjunction with Vision and Design: A Year of Bloomsbury, a campus-wide interdisciplinary program surrounding an exhibition of Bloomsbury art at Duke University's Nasher Museum of Art.

Keywords: John Maynard Keynes, Bloomsbury Group, economic policy, Great Depression, macroeconomics, Friedrich A. von Hayek, Keynesian economics, Austrian economics.

JEL Codes: B20, B22, B31, B25 


\section{I \\ Maynard Keynes of Bloomsbury \\ by Craufurd Goodwin}

My main message this evening is that John Maynard Keynes (Maynard to his friends), contrary to popular belief and recent caricatures in the media, was much more than a tax and spend liberal. Indeed, he was a liberal only in the original sense of that term, in that he placed the highest value on human freedom, and he believed that this freedom could most likely be gained and preserved within a smoothly functioning competitive market economy. Unlike many of the economists of his time, notably the so-called "American Institutionalists" with whom he is often mistakenly grouped, he was deeply suspicious of government and was constantly searching for solutions to economic problems through actions in the private sector rather than the public sphere. Maynard Keynes served in government for extended periods throughout his career, so he really knew whereof he wrote.

Keynes is best known, of course, for observing that a serious flaw in the competitive market economy is that the aggregate demand for goods and services tends to fluctuate over time and may be inadequate on occasion to sustain the potential production of the economy; unemployment and stagnation may result. Because he believed that monetary policy was unable to stimulate aggregate demand at critical junctures he turned to fiscal policy rather reluctantly, to taxation and public expenditure. So how is the Bloomsbury Group, that collection of artists and intellectuals with whom Keynes loved to hang out and whose art is exhibited in this museum, related to Keynes's pioneering macro-economics? In several ways, I suggest.

First, Maynard arrived at his conclusions about how the economy worked only after abandoning the simple rational actor hypothesis that was increasingly 
accepted by his economics colleagues beyond Bloomsbury. He looked for guidance about human behavior to the literature of psychology, the writings of Sigmund Freud, Wilfred Trotter, and others. In this his Bloomsbury friends joined enthusiastically; their interest in human behavior, like that of Maynard was whetted by their experiences during World War I, a conflict in which they found just about everyone to be irrational. The Hogarth Press, operated by Leonard and Virginia Woolf published the complete works of Freud, translated by Lytton Strachey's brother James. Lytton, whose portraits we can see in this exhibition, used insights from psychology to revolutionize biography and autobiography, what we now call "life writing," through his collection of essays entitled "Eminent Victorians" (1918). Strachey's biographical style- ironic, sardonic, satirical, was picked up by Keynes in his own widely influential Economic Consequences of the Peace and in other writings, collected for the most part in two volumes he called Essays in Biography and Essays in Persuasion.

The second approach to the economy taken by Keynes from his Bloomsbury friends, in addition to the use of psychology and biography, became the center-piece of his macro economics; this was a clear focus on the demand side of markets. The Bloomsburys discovered early on that the major problem in the arts was not to encourage artists to produce but to persuade demanders to buy. And demanders, they discovered, were complicated creatures. Keynes specifically and repeatedly rejected what he considered the simplistic Benthamite picture of humans as homogeneous and predictable utility maximizers. He agreed with the other Bloomsburys that humans purchased goods and services for reasons other than those that could easily be subsumed under the term optimization. It was not only to the celebrated phenomenon of "animal spirits" that Keynes turned for an explanation of human unpredictability, he examined also the particular buying characteristics of various categories of economic actor: the mercurial expectations of investors, the fearfulness of many seeking greater liquidity, and the stolid consumption behavior of the mass of the population. 
Keynes knew well how his close Bloomsbury friend Roger Fry had decomposed the demand for the arts into categories of demanders with different behavioral characteristics, to which Fry gave names like "classicists","Philistines," "snobbists," and "the herd." Maynard performed a similar decomposition for the economy as a whole.

The others in the Bloomsbury Group helped to give to Maynard a deep appreciation of the manifold consequences of failure in a market economy. More conventional economists in his time, as in ours, have been inclined to see recession and depression as regretable phenomena that cause "inefficiency": meaning loss of output and resources misapplied. The Bloomsburys, with their deep concern for history and current events, could see that economic failure could lead quickly also to social and political turmoil, with dire consequences. Humans, they observed, were reluctant to endure very much economic suffering and if a plausible solution were promised them, they turned easily to dictators and totalitarian rule, as they did in Germany and Italy in the 1930s. In 1925 Leonard Woolf wrote an insightful pamphlet for the Hogarth Press entitled Fear and Politics . Maynard Keynes' General Theory a decade later might well have been called Fear and Economics.

But the impact of Bloomsbury on Keynes went well beyond his macroeconomics, It went, for a start, to the deep philosophical question of what is the purpose of human life, and therefore of the economy. At the time when national accounts were being constructed for the first time and being taken as a measure of human progress between the two world wars, the Bloomsburys were groping for a richer measure of human accomplishment; this they called "civilization." The notion had its origins in the dictum of the Cambridge ethicist G. E. Moore that the ultimate values in human life lay in states of mind resulting from the pursuit of truth, beauty, and love. Moore's message was restated by Roger Fry to be a concern with the imaginative life of human beings, meaning their creative engagement with literature, the arts, and pure science. The utilitarian metric of 
the consumption of goods and services per capita was rejected by the Bloomsburys as an input measure, missing the essence of human accomplishment. To accept this dictum was an exceptionally long jump for a prominent economist like Keynes, away from his economist brethren and toward his Bloomsbury friends, but he took it with alacrity.

Taking account of this focus on civilization as the standard by which human progress should be judged, Keynes unusual personal life can be understood. He insisted that humans generally should move beyond the Benthamite prescription in which they spent their time pondering consumption alternatives using a pleasure-pain calculus. Maynard urged that, instead, they devote any spare time to sustaining the imaginative life, especially through participation in the activities of non-governmental organizations in ways that made use of their highest skills. Following this principle Keynes himself spent many of his own waking hours promoting the arts through the Camargo Society for the ballet, the Cambridge Arts Theatre, the Royal Opera House, Covent Garden, the Contemporary Art Society, the London Artists Association, and other groups. Perhaps his most lasting imprint on the arts is as the principal designer of the Council for the Encouragement of Music and the Arts and its successor organization the Arts Council of Great Britain; these sought to provide a vehicle for public support of the arts with minimal public control. This model lies at the roots of the National Endowment for the Arts in the United States, the Canada Council, and other arts funding agencies created after World War II.

What lessons may we draw from this unusual life of perhaps the most influential economist of the twentieth century. One may be that there is a stronger case than most economists will admit for the broadly inter-disciplinary education and experience that shaped his world. We may be permitted even to speculate that if more of our own macro-economists had had a life more like that of John Maynard Keynes we might not be in the mess we are in today.

A symbolic act by Keynes when he was raised to the peerage was to select 
for his title not Lord Keynes of Cambridge, nor Lord Keynes of the City, places with which his name is most commonly linked, but instead Lord Keynes of Tilton, after the humble little house in Sussex, next to the Charleston Farm House, where he spent many of his happiest hours with his Bloomsbury friends.

\section{0a6}

\section{II}

\section{Keynes as Policy Advisor}

\section{by E. Roy Weintraub}

After a short stint clerking in the India Office from 1906 to 1908, Keynes left to teach economics at Cambridge. He returned to government service -- in the Finance section of the Treasury - at the start of World War I. There, he became a trusted advisor to Prime Minister Asquith, frequently accompanying the prime minister and his wife on weekend escapes to their home outside London, where Keynes often partnered Lady Asquith in bridge. This kind of access to power shouldn't be surprising. Keynes had been an Eton Scholar, a King's College Honors graduate, a Cambridge Lecturer and was to be a Fellow of King's. His father was a Cambridge don, and his mother was to be the Mayor of Cambridge. He had been born and trained to take his place among Britain's governing elite.

As an advisor to the Treasury, he accompanied the Liberal Prime Minister Lloyd George to Versailles, to help develop plans to settle German reparations and inter-allied war debts. Keynes was appalled by what transpired, what he saw as the grotesque political logrolling in defiance of economic logic. He 
resigned from the Treasury delegation and, in a state of great agitation, wrote his masterful polemic The Economic Consequences of the Peace.

He thundered:

"The policy of reducing Germany to servitude for a generation, of degrading the lives of millions of human beings, and of depriving a whole nation of happiness should be abhorrent and detestable - abhorrent and detestable, even if it were possible, even if it enriched ourselves, even if it did not sow the decay of the whole civilized life of Europe. Some preach it in the name of justice. In the great events of man's history, in the unwinding of the complex fates of nations, justice is not so simple. And if it were, nations are not authorized, by religion or by natural morals, to visit on the children of their enemies the misdoings of parents or of rulers."

This public blast, together with withering verbal portraits of America's Woodrow Wilson, France's Clemenceau, Italy's Orlando, and Great Britain's Lloyd George gave Keynes a public persona. It also endeared him to his Bloomsbury friends - not only had he had created a work of art, but he had melded economic expertise, a passion for justice and fairness, and a willingness to set his own views apart from popular wisdom.

As Keynes had forecast, The Versailles Treaty led to monetary collapse and massive unemployment across Europe. We in the United States tend to think of the Great Depression as beginning in 1929, but the post war collapse of Europe was at depression levels. Over the 1920s Great Britain for example had only one year with an unemployment rate below ten percent. It was in this period that Keynes, the Cambridge don, policy advisor, and public scold, turned to economic journalism. He began to write most of the economics articles for the The Nation and Atheneum, the unofficial house publication of Britain's Liberal Party, and at the same time he engaged in frequent bouts of letter writing and controversializing in The Times and The Manchester Guardian, as well as in US 
newspapers and journals of opinion like The New Republic.

British leaders, Conservative leaders, were campaigning in 1923 and 1924 on a return to the gold standard at prewar parity, a move that would make British goods significantly more expensive to sell outside Britain. Keynes argued that the effect of this would be to reduce the wages of English workers in export industries in order that those goods could stay competitive in world markets. He judged that wage reductions would hit workers in coal mining and shipbuilding especially hard.

This view was theorized in his 1923 book A Tract on Monetary Reform, a slender volume that emerged from a set of articles in The Manchester Guardian. There Keynes argued

"Since I regard the stability of prices, credit, and employment as of paramount importance, and since I feel no confidence that an old-fashioned gold standard will even give us the modicum of stability that it used to give, I reject the policy of restoring the gold standard on pre-war lines."

Alas, in 1925 the Conservative government did indeed return Great Britain to gold at the prewar dollar exchange rate for the pound of $\$ 4.86$. The general strike of 1926 was the result. Workers refused to accept the slashing of their wages. The Conservative Prime Minister Baldwin, and Chancellor of the Exchequer Winston Churchill, broke the strike by a series of harsh measures, and most workers returned to work by 1927. But a number of miners lost jobs permanently and suffered hardships so severe that many mining communities of northern England have not, to this day, voted for Conservative leaders. The Labor Party emerged stronger from the strike and post strike wreckage. Keynes's Liberal Party began to crumble. And inevitably Keynes penned a new tract titled "The Economic Consequences of Mr. Churchill".

In 1929, with Labour and Conservative government parties contesting a general election, Keynes urged Liberals to abandon Asquith and throw their 
support instead to Lloyd George. He co-authored a pamphlet with Hubert Henderson, titled Can Lloyd George Do It? There, for the first time, Keynes laid out his policy views on combating depression levels of unemployment. Kevin Hoover will be talking about how those ideas were theorized in his 1936 magnum opus, A General Theory of Employment, Interest and Money. But by 1929 Keynes is quite clear about what would constitute a correct economic policy for a depression:

"Why is it not enough to offer facilities and encouragement to private enterprise? Whether we like it or not, it is a fact that the rate of capital development in the transport system, the public utilities and the housing of this country largely depends on the policy of the Treasury and the government of the day. It is not a question of choosing between private and public enterprise in these matters. The choice has already been made. In many directions it is the question of the state putting its hand to the job or of its not being done at all. Roads, re-forestation, reclamation and drainage, electrification, slum clearance and town planning, the development of canals, docks and harbors; these are the things which need to absorb large sums of capital today, and in every case the initiative necessarily lies with the public authority. ...[But] the object is not to develop state enterprise as such. The object is to develop and equip the country through the instrumentality of such forms of organization as already exists and lie ready to our hands."

With respect to Conservative objections to massive government investment in infrastructure, Keynes wrote:

"Negation, Restriction, Inactivity - these are the Conservative government's watch words. Under their leadership we have been forced to button up our waistcoats and compress our lungs. Fears and doubts and hypochondriac precautions are keeping us muffled up indoors. But we are not tottering to our graves. We are healthy children. We need the breath of 
life. There is nothing to be afraid of. On the contrary. The future holds in store for us far more wealth and economic freedom and possibilities of personal life than the past has ever offered. There is no reason why we should not feel ourselves free to be bold, to be open, to experiment, to take action, to try the possibilities of things. And over against us, standing in the path, there is nothing but a few old gentlemen tightly buttoned-up in their frock coats, who only need to be treated with a little friendly disrespect and bowled over like ninepins. Quite likely they will enjoy it themselves, when once they have got over the shock."

The problems that Keynes saw in the 1920s and 30s concerned the financial instability of international capital and trade flows, and the inability of governments singly to help create lasting employment. He thus argued for multinational management of the world financial system, by organizations staffed with experts. In time, his work at the 1944 Bretton Woods Conference would instantiate his vision by creating the World Bank and the International Monetary Fund.

Keynes's was a tireless advocate of investment as the engine for creating income and employment. His belief that intelligence and will could solve economic problems never waivered. He was confident that expertise could serve humankind.

Keynes was no Socialist. Neither had he any sympathy for the Tories. He was a classical Liberal whose advice on economic policy was fully consistent with his views on human affairs.

Let me close then with what might stand as Keynes's credo:

"The political problem of mankind is to combine three things: economic efficiency, social justice, and individual liberty. [Efficiency] needs criticism, 
precaution, and technical knowledge; [social justice needs] an unselfish and enthusiastic spirit, which loves the ordinary man; [individual liberty needs] tolerance, breadth, appreciation of the excellencies of variety and independence, which prefers, above everything, to give unhindered opportunity to the exceptional and the aspiring. [Social justice] is the best possession of the great party of the proletariat. But [economic efficiency and individual liberty] require the qualities of [my Liberal] party which, by its traditions and ancient sympathies, has been the home of economic individualism and social liberty."

20\%

III

\section{Keynes and Economics}

\section{by Kevin D. Hoover}

Keynes's stock as an economist rises in inverse proportion to the fall in economic indicators. The Wall Street Journal often reminds us that Keynes is dead. Yet, last November, writing in the New York Times, N. Gregory Mankiw, Harvard economics professor and former chairman of George W. Bush's Council of Economic Advisors, found a well worn passage from Keynes's masterwork, The General Theory of Employment Interest and Money, that speaks to our time:

"At the present moment people are unusually expectant of a more fundamental diagnosis; more particularly ready to receive it; eager to try it out, if it should be even plausible. But apart from this contemporary mood, the ideas of economists and political philosophers, both when they are right 
and when they are wrong, are more powerful than is commonly understood. Indeed the world is ruled by little else. Practical men, who believe themselves to be quite exempt from any intellectual influences, are usually the slaves of some defunct economist. Madmen in authority, who hear voices in the air, are distilling their frenzy from some academic scribbler of a few years back." [General Theory, p. 383]

Keynes himself is now that defunct economist. The Wall Street Journal knows that he is defunct, but fears that - zombie-like - he won't stay down. Mankiw too knows that he is defunct, but sees a friendly ghost.

My job is to explain Keynes's economics and its influence. I leave it you to decide whether Keynes is the living dead or Caspar. There is not time, nor would it suit this audience, for me to give a technical account of Keynes's economics. What I can do is to note some of its central ideas.

\section{The Fallacy of Composition}

For Keynes people are heterogeneous - each is situated differently, each has different tastes, different capacities, different beliefs. Yet, they form a society. And extending our reasoning from individual interactions to the whole economy is misleading. It commits a fallacy of composition. The quickest way for an individual from New Orleans to Baton Rouge is Interstate 10; but it is not the quickest way to get the whole population of New Orleans to Baton Rouge.

A key fallacy of composition in economics is a false analogy from elementary exchange to the economy as a whole. Robinson Crusoe faces a microeconomic problem: how to do the best he can with scarce resources. The appearance of Friday present a new, but still microeconomic, problem. Crusoe's and Friday's different skills and different endowments give rise to mutually beneficial trade, and there is never any reason other than wanting to enjoy sleep or meal or a swim that they should be unemployed. In contrast, macroeconomics concerns a whole economy - say, Friday's tribe or, for Keynes, Mandeville's 
grumbling hive of the "Fable of the Bees." A Lincoln Navigator or dinner at the Magnolia Grill is a dispensable luxury, but if enough of us dispense with such luxuries the autoworker and the busboy go without their dinner: "the gay of tomorrow are absolutely indispensable to provide a raison d'ettre for the grave of to-day" (General Theory, pp. 105-106). Unlike Robinson and Friday, workers in a complex economy can be unemployed; the economy can operate at less than full capacity.

Keynes was keenly aware that the complexity of the economy depends on the institution of money, which allows us to obtains goods from people we'll never know, living lives that we can hardly imagine, in places we'll never see. Robinson and Friday may be selfish, but in an obvious sense they work for each other. If they save, they save by laying up stores. We too work for each other, but only indirectly. Directly, we work for money. And when we save, we save money, and do not demand the work of others. The process of my abstaining from spending leading to another's loss of income and his abstaining from spending, leading to still another's loss of income . . . and so on is Keynes's famous expenditure multiplier. The multiplier works the other way too expenditure (yours or mine or the government's) gives some people income which, if they spend it, gives other people income . . .and so forth. The expenditure multiplier is the intellectual basis for President Obama's stimulus package.

Keynes did not believe that the private sector always failed us, but neither did he believe that it always and everywhere found and effected every valuable exchange. It fails us frequently enough and for long enough periods that the economy sometimes runs cold and unemployment sometimes runs high. Yet, Keynes possessed a self-confident optimism (or arrogance perhaps) and also thought that, with a little bit of shrewd macroeconomic management (guided by Cambridge men, of course), the economy could run warmer and unemployment could be kept low. Then, through the miracle of compound growth rates, we 
would soon solve the material economic problem. The real challenge that he saw for the grandchildren of his generation - provided that management of the economy was enlightened - was the problem of what to do with our leisure. This is Keynes of Bloomsbury.

\section{Uncertainty}

The multiplier explains the process of getting into and out of trouble, but what started the first place? Keynes's answer (surprisingly like that of the Austrian economists - often his most vocal opponents) is time and ignorance. The future matters to economic decisions, but we cannot know the future. Institutions have evolved to cope with time and ignorance - insurance, for example. As a chairman of two insurance companies and the author of a Treatise on Probability, Keynes understood insurable risk. The casino cannot predict each spin of the roulette wheel; the life insurance company cannot predict the day of each death; but the averages and their variability are known precisely. You take a chance on roulette; the casino calculates its return.

Keynes would no doubt see the onset of our latest financial collapse as the result of an intellectual error - confusing uninsurable uncertainty of the valuation of mortgage-backed financial derivatives with insurable risk. He illustrates uncertainty:

"the prospect of a European war is uncertain, or the price of copper and the rate of interest twenty years hence, or the obsolescence of a new invention, or the position of private wealth owners in the social system of 1970. About these matters there is no scientific basis on which to form any calculable probabilities whatever. We simply do not know." [Keynes 1937, pp. 113114; Collected Works, vol. 14.]

For Keynes a conventional response to uncertainty is better than paralysis: "the necessity for action and for decision compels us as practical men to do our best to overlook [uncertainty] and to behave exactly as we should if we ..." 
could calculate the prospects and the risk [Keynes 1937, pp. 113-114; Collected Works, vol. 14.] Such a calculation requires a view of those prospects; yet they too are uncertain, and "sanguine temperament and constructive impulses" determine our positive evaluation of them:

"If human nature felt no temptation to take a chance, no satisfaction (profit apart) in constructing a factory, a railway, a mine or a farm, there might not be much investment merely as the result of cold calculation." [General Theory p. 150]

Elsewhere Keynes refers to "the spontaneous urge to action rather than inaction" as animal spirits and

"if the animal spirits are dimmed and the spontaneous optimism falters, leaving us nothing but mathematical expectation, enterprise will fade and die; - though fears of loss may have a basis no more reasonable than hopes of profit had before." [General Theory, pp. 161-162] He doesn't put it this way, but there is an expectations multiplier as well as an expenditure multiplier that can turn a boom into a bubble or a slump into a rout.

\section{The Role of Government}

When the whirlpool of speculation destroys enterprise, when the financial bubble bursts, when animal spirits dim, and multipliers head south, investment collapses, businesses shut down, and unemployment rises. Then what? An inveterate optimist, Keynes's animal spirits were high. And possessed of a facile pen, an elegant prose style, and access to high places, he urged the government to action.

The General Theory is light on policy prescriptions - it is by no means the bible of deficit finance and big government that critics who know it without reading it suppose. Keynes would rather avoid slumps than fight them, which argued for sound passive policies (especially monetary policies) to prevent emergencies. He would certainly have welcomed the automatic fiscal stabilizers, 
such an unemployment insurance payments that rise as output falls. He did not call for the heavy regulation of financial markets, but for disincentives to too rapid turnover. Generally, small disincentives would probably be sufficient, but in a whimsical vein he suggested that perhaps "the purchase of an investment [should be] permanent and indissoluble, like marriage, except by reason of death or other grave cause" (General Theory, p. 160).

Nor was Keynes an enemy of the price system, arguing against wage and price rationing in the Second World War. The private sector and the businessman normally knows their own interests and these typically coincide well enough with those of society. Nor was he a friend of inflation, warning in his prophetic Economic Consequences of the Peace against debauching the currency.

Yet, when the private sector misses its cue, when the price system fails adequately to coordinate, when the slump looms, Keynes advocates government intervention. He called it the "socialization of investment"; we call it "the stimulus." He preferred not to use the simple expenditure multiplier to buy us out of the recession; but to use it to jump start the expectations multiplier - to buoy the animal spirits of private business so that their own additions to investment would stimulate demand.

\section{Do It Now}

Keynes was not timid. President Obama's slogan, "the fierce urgency of now," would resonate for him. Conservative critics have generally hated this about him, seeing in it a kind of recklessness with respect to the future. His most famous quip, "In the long run we are all dead" (Tract on Monetary Reform, p. 65), is offered as exhibit one in his opponents' brief. But the quotation is taken out of context. Keynes does not hold up Aesop's gay grasshopper as our proper model; nor does he denigrate Aesop's grave ant. His point is rather that it is not much use to say that, on average, the temperature is mild, the sun shines, and the winds are fair, when summers burn, winters freeze, and hurricanes punctuate 
the autumn. Ant and grasshopper alike live or die in the short-run and not in the average. Economists may be right about their analysis of the long run, but if they cannot say anything enlightening about the business cycle, they are not much use.

There can be little doubt that Keynes would support macroeconomic stimulus today. But Keynes was always a skeptic and a contrarian. Let me end with Keynes's assessment of the early days of the New Deal. If you don't hear its echo today, I have failed in my job. To Franklin Roosevelt, he wrote:

"You are engaged on a double task, recovery and reform - recovery from the slump, and the passage of those business and social reforms which are long overdue. For the first, speed and quick results are essential. . On the other hand, even wise and necessary reform may . . . impede and complicate recovery. For it will upset the confidence of the business world and weaken its motives to action before you have had time put other motives in place. . . In particular, . . . I cannot detect any material aid to recovery in the NRA [i.e., Roosevelt's National Recovery Act] . . . which is essentially reform and probably impedes recovery, [and] has been put across too hastily, in the false guise of being part of the technique of recovery." 


\section{IV \\ Keynes and Hayek}

by Bruce Caldwell

My charge tonight is to talk a little about the relationship between Keynes and the Austrian economist Friedrich Hayek. The two are typically portrayed as intellectual rivals, and the differences between them juxtaposed in rather broad terms: Keynes as favoring government regulation of the economy, in particular control of the business cycle by deficit spending during a downturn; Hayek as favoring a free market economy with a minimal intervention by the government. Now though there are certainly elements of truth in such broad portrayals, part of what this panel has done, I hope, is to establish that the actual history is always more complicated, nuanced, and as an historian I am obliged to add, more interesting.

So what about the actual Keynes-Hayek relationship? The first perhaps surprising fact to note is that when Hayek was a college student in Vienna after World War I Keynes was one of his heroes, as he was to many central Europeans after the war. This was because of Keynes' condemnation of the harsh terms of the Versailles Peace Treaty in his Economic Consequences of the Peace. Keynes' criticisms of the treaty had little effect, and Hayek was among those who witnessed firsthand the devastating hyperinflation that wiped out the savings of the middle classes in Austria and Germany in the early 1920s, which in many people's minds was instrumental in paving the way for the rise of fascism there. This gave Hayek a lifelong appreciation of the dangers of inflation.

About a decade later Hayek and Keynes crossed swords. In 1931 Hayek was invited to the London School of Economics to give four lectures on monetary theory. The lectures were published that year as a book with the title Prices and Production. People who attended later told him that he was nearly 
incomprehensible when he was reading the lectures, but whenever he answered questions he was quite clear. Of course nothing impresses an academic audience like someone being incomprehensible, so the end result was that they offered him a job.

In the summer of that year, even before he even began teaching, he published a review of Keynes' new book, A Treatise on Money, a book that Keynes had been working on for years and which was supposed to establish his credentials as a major monetary theorist. This initiated a fierce debate over their respective theories of the business cycle.

I say fierce because it really was unprecedented: one of Keynes' fellow Cambridge economists chastised Keynes in print afterwards, likening his assault on Hayek to "body-line bowling" - this being a reference to the game of cricket, when the bowler aims for the batsman's body rather than for the wicket, a striking metaphor.

The grounds for the debate were really quite simple - both men had in their respective theories of the cycle drawn upon a framework that had been developed by a Swedish economist named Knut Wicksell. Wicksell wrote in German. Hayek, of course, read German. Keynes, for his part, in a footnote in the Treatise made the fatally self-deprecating remark that "in German I can only clearly understand what I know already." It was as if Keynes had painted a bull's-eye on the cover of his book. Hayek's critique was that Keynes had only borrowed a portion of Wicksell's framework, ignoring completely the capital theoretic foundations that Wicksell had developed in another book. In contrast, Hayek had incorporated in an essential way Wicksell's capital theory into his.

In its own quiet way, Hayek's review was a polite but really quite devastating attack: he basically said that Keynes had not done his homework. (Gunnar Myrdal, who would share the Nobel prize with Hayek some 40 years later, was even less flattering, noting Keynes' book as an example of the British penchant for unnecessary originality.) If we recall that Keynes was a Cambridge 
don, the editor of The Economic Journal, and a major public figure in England, while Hayek, who at age 31 was 16 years Keynes' junior, a young upstart from another county, and that this was all taking place as the downturn of 1930 was turning into the Great Depression, we can see that the stakes were pretty high.

Keynes was apoplectic about the review. His biographer noted that Keynes' copy of it was the most marked up document in Keynes' collection of writings by others. As is usual in the academic world, he expressed his displeasure by writing a response to it that was published a few months later. What was unusual is that Keynes used the review not simply to defend his own theory but also to attack Hayek's book. And what an attack it was! I will quote the most famous passage which will give you some idea of the general tone:

"The book as it stands seems to me to be one of the most frightful muddles

I have ever read, with scarcely a sound proposition in it.... It is an extraordinary example of how, starting with a mistake, a remorseless logician can end up in Bedlam. “

Body-line bowling indeed.

Both men eventually left the battle to work on new books. Keynes finished first, publishing in 1936 The General Theory, probably the most important book in $20^{\text {th }}$ century economics, if one measures importance by the impact that it had on the thinking of economists and practice of economic policy. Hayek's book, The Pure Theory of Capital, published 5 years later, was almost unreadable, frankly; and in any event little read. He was to make his mark with another book, published as the war was coming to an end, The Road to Serfdom.

There is a final twist to the story. Once the war had begun, the KeynesHayek relationship improved dramatically. They were on the same side in their recommendations for financing the war, with Hayek writing a strongly favorable review of Keynes 1940 pamphlet, "How to Pay for the War." When the Battle of Britain began the London School of Economics was evacuated to Cambridge, and 
Keynes found Hayek rooms at Kings College there. Finally, and most remarkably, after Keynes read The Road to Serfdom he sent Hayek a letter in which he said,

"You will not expect me to accept quite all the economic dicta in it. But morally and philosophically I find myself in agreement with virtually the whole of it; and not only in agreement with it, but in a deeply moved agreement. "

Hayek for his part said in a later interview when asked to name the two people with whom he would most like to have a dinner and conversation with, it was Keynes and Joseph Schumpeter. So as I said, the actual relationship between these two men was more complicated and interesting than one might first suppose.

For the time that remains I'd like to shift gears and look briefly at what I see as the chief differences between Hayek and Keynes. One of these of course has to do with their analyses of the business cycle. I think that the best starting point is to say that both of them were fully cognizant of the fact that a market system is occasionally plagued by a business cycle. I say this for two reasons: first, it sometimes seems like people today are surprised that a cycle could ever happen. And second, Hayek is sometimes portrayed as someone who thought that markets always work just fine. This is a man whose first book was titled Monetary Theory and the Trade Cycle. Suffice it to say that Hayek was no Dr. Pangloss when it came to the workings of a market economy.

It turns out that Hayek's theory about the causes of a typical cycle offers a pretty good description of at least part of what happened in the latest meltdown, especially in terms of the Fed's interest rate policy and its effects on the housing sector. In Hayek's theory, problems start when the market rate of interest is held 
too low for too long. This always politically popular policy leads to malinvestment - too many investment projects get started that cannot ultimately be sustained. When people realize what has happened, investment spending collapses and a recession begins. Recessions are the painful but necessary adjustment that returns the system back to equilibrium.

Where Keynes and Hayek differed of course was in their response to the crisis. For Hayek, because a recession was the system moving itself back to equilibrium, he felt that any attempt to further inject credit into the system would just prolong the period of malinvestment, and ultimately set the stage for a bout of inflation later. Hayek's counsel to simply sit back and let the system adjust was as politically popular during the 1930's as it is today - it was a nonstarter.

Hayek's his fears about inflation did not materialize after the Great Depression ended. On the other hand, they did materialize during the stagflation of the 1970's that marked the end of the activist Keynesian policy in the United States. Which of these 2 episodes has more relevance for the downturn of aught 8 is anyone's guess. The danger, as both Keynes and Hayek recognized, was that fiscal and monetary stimulus will go on for too long. In many people's minds, the question boils down to this: Will Washington have the requisite knowledge and political will to start reducing the stimulus at just the right time?

This scary question brings us to a second difference between Keynes and Hayek. It was captured beautifully by Keynes' biographer Sir Roy Harrod, who talked of "the presuppositions of 6 Harvey Road," (that was the Keynes' family address in Cambridge), the idea that

"Reform, in the larger as in the smaller sphere, was to be achieved primarily and principally by the discussion of intelligent people. In all vital matters their views would prevail. Public opinion would be wisely guided." 
Keynes was supremely confident that he and a small group of Oxbridge trained experts could effectively manage the economy. Indeed, he was constantly making policy pronouncements, and often changing his mind, so much so that he was often criticized or caricatured in the press. After one notorious policy flipflop, there was a cartoon of Keynes as "the boneless man," and there was even a riff on the old joke about economists: "When five economists gather, you get six different opinions, with two of them held by Keynes."

Hayek for his part often spoke about the limits of our knowledge and the hubris of reason: we just do not have enough knowledge to control something as complex as an economy. George Will recently quoted Hayek on this point: "The curious task of economists is to demonstrate to men how little they know about what they imagine they can design."

He was also wary about the effects of government intervention on the ability of ordinary people to make decisions. As he wrote in The Road to Serfdom, "The more the state plans, the more difficult planning becomes for the individual." The government itself can be one of the forces that induces uncertainty, and there is plentiful evidence of that happening in recent months.

Taken by itself, Hayek's message about the limits of our knowledge suggests the importance of proceeding with caution. If one links it up with other arguments about the nature of the political process, for example, those that are associated with the public choice school of James Buchanan, one's confidence that the political process will yield the right policy is further chastened.

Hayek's message, in short, is a much more depressing one than is Keynes'. These are depressing times, with many people hurting. But tonight is supposed to be a celebration of the start of a new Center, and of Keynes and Bloomsbury. So I will end with one of my favorite Keynes' quotes, one that is always popular with my students, and one which should make our transition to the reception awaiting us a bit easier. A few weeks before he died Keynes was asked in an 
interview if there were anything that he would have done differently. His response was: "I would have drunk more champagne!"

don 